\title{
ДИНАМІКА В АРГУМЕНТАЦІї
}

\section{В.В. Навроцький}

Помітною рисою переходу від класичної раціональності до некласичної, яка характеризується, зокрема, новим логічним і методологічним оснащенням наукових досліджень, новим поглядом на соціальні дії і соціальну взаємодію, є зміни у розумінні аргументації. Вони зумовлені, зокрема більш пильною увагою дослідників до динамічних аспектів функціонування знань.

Аргументація є предметом багатьох наукових дисциплін - логіки, риторики, психології, лінгвістики, соціології, дисциплін, що вивчають штучний інтелект тощо. Теорія аргументації інтегрує різноманітні підходи, що розробляються засобами цих дисциплін, і це дозволяє їй виконувати певну методологічну функцію стосовно наукового дискурсу.

У вузькому розумінні теорія аргументації розглядається як логічна теорія доведення, до методів якої належать, зокрема, виведення тези iз прийнятих положень, її спростування, перевірка тези на сумісність iз раніше обгрунтованими положеннями тощо. Логічні методи застосовуються у різних видах аргументації. Це легко продемонструвати на прикладі емпіричної і теоретичної аргументації. Так емпіричне підтвердження $є$ по суті індуктивним, а теоретична аргументація будує дедуктивне обгрунтування. Кожна нова логічна теорія вносить певні зміни у розуміння аргументації.

Взагалі кажучи, теорія аргументації досліджує різні способи обгрунтування і спростування, що вживаються в ході мовної комунікації, а не тільки логічне доведення і спростування, не зводить аргументування до логічного доведення істинності або хибності тверджень. В аргументуванні задіяні також процедури, які відсутні в чисто логічному доведенні: вибір методу аргументування, виправдання його

Актуальні проблеми духовності

(Відп. ред.: Я.В. Шрамко)

Кривий Ріг (2006), 209-217 
мети тощо. Однак тут аргументація буде розглядатися тільки як логічна діяльність і предметом обговорення будуть ті логічні методи, які дозволяють відобразити динаміку аргументування.

Логічні дослідження аргументації спрямовані, зокрема, на побудову логічних моделей діалогу, яка спирається на формальну репрезентацію структури і динаміки дискурсу. I це зрозуміло, оскільки суттєвий внесок у теорію аргументації логіка спроможна внести тільки в тому випадку, якщо логічні правила і процедури виводу будуть максимально наближені до процесів реального міркування. Саме у цьому напрямі і здійснюється спроба розглянути логічні методи аналізу аргументації.

Побудова правильної аргументації передбачає врахування того, що міркування здійснюються при неповній інформації і нові дані можуть послабити обгрунтованість переходу від засновків до висновку, через що останній може бути скасованим. Відповідні рекомендації стосовно таких міркувань полягають у дозволі здійснювати вивід, якщо не відомі обмеження, наприклад, якщо немає підстав для виведення протилежного висновку. До таких міркувань природно застосовується гіпотеза замкнутого світу і так званий принцип інерції: міркування зберігає свій статус правильного міркування доти, доки не з'являться умови, які можуть змінити цей статус. Невідомі обставини вважаються нерелевантними для оцінки таких міркувань.

У логіці динаміка аргументації репрезентується змінами у доведеності речень. Донедавна динамічна репрезентація міркувань здійснювалась у термінах класичного логічного випливання із додаванням відповідних обмежень на виведення. Найбільш впливовими виявилися немонотонна логіка [5] і моделі, які містять операції розширення, скорочення і перегляду інформації [1].

У немонотонній логіці формалізація міркувань здійснюється через побудову теорії, яка складається з аксіом двох типів - аксіом класичної логіки і власних (нелогічних) аксіом теорії. Додавання до теорії певних допущень у статусі нових власних аксіом розширює ї. 3 отриманого розширення породжуються теореми. Таким чином, речення виводиться в деякій теорії немонотонним способом, якщо воно виводиться монотонним способом з її аксіом і допущень. На відміну від класичної дедуктивної системи, у немонотонній системі збільшення множини засновків не приводить до простого збільшення множини теорем. Деякі попередні висновки можуть бути видалені.

Істотною ознакою немонотонних логік такого типу $\epsilon$ замикання множини формул правилами виводу. Це означає, що множина логічних наслідків з деякої множини аксіом і допущень уже міститься в 
цій множини, тобто, застосування логічних операцій не веде до її зміни. Тому її називають фіксованою точкою або стійким розширенням. Зрозуміло, що така репрезентація міркувань є власне кажучи статичною. Динаміка виражається тільки в переході до нових допущень i, відповідно, до нових фіксованих точок. До числа недоліків систем немонотонної логіки належить також і те, що прийняттям нового допущення стверджується пріоритетність нової інформації.

А до очевидних достоїнств немонотонної логіки варто віднести її здатність моделювати ментальні стани індивідів. Так в одній із семантичних версій немонотоного підходу, а саме в автоепістемічній логіці, репрезентуються переконання індивіда стосовно його власних переконань [6]. Центральним поняттями в цій логіці $є$ поняття автоепістемічної інтерпретації, тобто такої інтерпретації, у якій для усякого висловлення $p$, висловлення «Індивід переконаний, що $p$ » якщо і тільки якщо $p$ міститься у відповідній теорії. Стан переконання індивіда, що характеризується такою теорією, є стійким у тому розумінні, що подальші висновки не можуть бути породжені індивідом, що перебуває в цьому стані. Слід зауважити, що динаміка станів переконання виражається знову-таки тільки через перехід від однієі теорії (від стійкого розширення попередньої теорії) до іншої теорії.

Радикально відмінним від зазначеного вище способу моделювання скасовуваності висновків є застосування некласичного відношення логічного випливання. Відомо, що класичне відношення логічного випливання виконує умову монотонності: $A_{1} \ldots A_{n} \vdash B / A_{1} \ldots A_{n}, X \vdash B$, де речення $A_{1} \ldots A_{n}$ - допущення (засновки), речення - висновок, речення - нове допущення (засновок), символ $\vdash$ позначає доведеність і символ / позначає перехід від засновку до висновку. Альтернативним засобом запису властивості монотонності є вживання класичної операції логічного випливання $C n$ (замикання множини формул правилами виводу): якщо $\Gamma \subseteq \Delta$, то $C n(\Gamma) \subseteq C n(\Delta)$, тобто, якщо множина речень $\Gamma$ власно включена до множини речень $\Delta$ або дорівнює останній, тоді множина наслідків із множини речень Г власно включена до множини наслідків із множини $\Delta$ або дорівнює їй.

Некласичне відношення логічного випливання не виконує умову монотонності. Вона заміняється умовою обережної (обмеженої) монотонності: якщо множина формул Г включається у множину формул $\Delta$, яка у свою чергу, включається у множину наслідків множини $\Gamma$, що можуть бути скасовані, тоді ця остання множина включається у множину потенційно скасовуваних наслідків, отриманих із з множини формул $\Delta$ : якщо $\Gamma \subseteq \Delta \subseteq C(\Gamma)$, тоді $C(\Gamma) \subseteq C(\Delta)$. Тут $C$ позначає 
некласичну операцію логічного випливання, яка позначає множину наслідків, що можуть бути скасовані.

Зміни у доведеності репрезентуються також специфічними операціями на множині речень - збільшенням, скороченням і переглядом (ревізією). Із одним із способів побудови цих операцій, а саме із постулатами моделі, у яких описані властивості цих операцій, можна ознайомитися за джерелом [1].

Інший спосіб побудови названих операцій полягає в їх базуванні на понятті епістемічної укріпленості [7]. Відношення епістемічної укріпленості $\varphi \leq \psi$ змістовно описується в такий спосіб: речення $\psi$ принаймні так само епістемічно укріплене як і речення $\varphi$, якщо від $\varphi$ i $\psi$ неможливо відмовитися або якщо зміст речення $\varphi$ взагалі не $\epsilon$ предметом переконання, або якщо необхідність відмовитися від одного 3 $\varphi$ чи $\psi$ веде до відкидання $\varphi$ (чи обох). Епістемічна укріпленість відбиває відносну епістемічну значимість переконань відповідної теорії, яка пов'язується зі ступенем зміни, що зумовлена видаленням цих переконань.

Операція скорочення позначається символом «» і визначається в термінах відношення епістемічної укріпленості у такий спосіб:

$K \div \varphi=K \cap\{\psi \mid \varphi<\varphi \vee \psi\}$, якщо не виводиться $\varphi$, інакше $K \div \varphi=K$. Тут $K$ позначає множину речень, $\cap$ - операцію перетину множин, $<-$ сильну укріпленість і символ $\vee$ позначає диз'юнкцію.

Операція ревізії позначається символом «ж» і визначається за допомогою операцій скорочення і збільшення: $K * \varphi=(K \div \neg \varphi)+\varphi$, чи за допомогою функції вибору: $K * \varphi=\cap \gamma(K \perp \neg \varphi) \cup\{\varphi\}$. У цих формулах символ $\neg$ означає заперечення, +- операцію збільшення, $\gamma$-функцію вибору, яка репрезентує процедуру вибору з елементів або підмножин множини і $\cup$-операцію об'єднання множин. Вираз $(K \perp \neg \varphi)$ позначає множину всіх таких максимальних підмножин множини , з яких не випливає речення $\neg \varphi$. Якщо операція ревізії приймається за базову операцію, тоді операція скорочення визначається так: $K \div \varphi=K \cap K * \neg \varphi$.

Операція ревізії характеризує таку зміну, коли введення нових допущень може породити висновки, несумісні із висновками, що породжені раніше, і для того, щоб уникнути суперечливості, необхідно або здійснити заміну деяких попередніх висновків новими висновками (з одночасним відкиданням тих старих допущень, з яких випливають висновки, що відкидаються), або відмовитися від нових допущень (і отже висновків, що випливають з них). Отже тут також виникає проблема пріоритетності. 
I ще одне істотне зауваження на адресу цієї моделі, знову-таки пов'язане із класичним характером відношення логічного випливання, полягає в тому, що суперечлива множина переконань $є$ тривіальною в цій моделі, тобто такою, з якої випливає усе, що завгодно, а саме i істинні, i хибні речення. Це означає, що істина і хиба не розрізняються. Тоді і додавання до множини переконань такого переконання, що суперечить їй, і ревізія множини переконань суперечливою множиною переконань породжують тривіальну множину. Виявляється, що теорія, яка претендує на статус бути теорією ревізії переконань раціонального індивіда, стосується тільки тих індивідів, які не можуть мати суперечливих переконань. Але при обговоренні питання, чи $є$ індивід раціональним, чи ні, не існує достатніх підстав надавати перевагу несуперечливій множині переконань перед суперечливою множиною. Раціональні індивіди вже тому можуть мати суперечливі переконання, що вони можуть мати хибні переконання. Тому теорія ревізії переконань повинна враховувати, що раціональний індивід може мати суперечливі, але нетривіальні переконання [8, с. 217-218]. Вона має бути теорією про те, як він фіксує межи несуперечливості, як він змінює свої переконання, коли виявляє суперечливість у своїй системі переконань.

Стосовно замкненості множини речень i, відповідно, знання всіх їі наслідків, а також стосовно $\dddot{11 ̈ ~ н е с у п е р е ч л и в о с т і, ~ с л і д ~ з а з н а ч и т и ~ т а к е: ~}$ наша пам'ять організована у такий спосіб, який не дозволяє їй одночасно активізувати усі наші знання. Тому ми і не можемо знати всіх наслідків наших міркувань. I це $\epsilon$ відмітною особливістю нашої раціональності.

Однією з перших спроб позбутися проблеми дедуктивного замикання була побудова теорії, що містить множину базових речень і дедуктивні правила породження [4]. За цим підходом, певне речення вважається істинним, якщо базові речення істинні і до них правильно застосовані дедуктивні правила. У результаті виводу отримуємо відповідь на питання, чи $\epsilon$ у індивіда те чи інше переконання. Неможливість виведення всіх логічних наслідків із множини базових речень обумовлена неповнотою множини правил.

Феномен скасовуваності висновків досліджується і в логіках із динамічною семантикою [3]. Розробка динамічної семантики була відповіддю на вимогу, щоб інтерпретація дискурсів набула динамічного характеру. Класичний семантичний підхід визначає значення речень через опис умов їх істинності, а саме, як відношення між реченням i зовнішнім світом чи ситуацією, тобто як певне статичне відношення. $\mathrm{y}$ динамічній семантиці у першу чергу розглядається не відношення 
мови до світу, а відношення між мовою і інформацією про світ, відношення між реченням та інформаційною системою індивіда, або, якщо говорити у термінах когнітивної семантики, відношення до ментальної моделі індивіда, до його знань про світ.

$\mathrm{У}$ динамічній семантиці центральним поняттям $є$ поняття зміни інформаційного стану індивіда, якому адресоване повідомлення. Iнформаційний стан визначається як підмножина множини можливих світів (множин атомарних речень). У цій семантиці у центрі уваги опиняються надходження нової інформації, наслідки її додавання до інформаційного стану індивіда. Якщо результатом вимовляння речення є новий інформаційний стан, тоді можна говорити, що значенням цього речення є зміна інформаційного стану індивіда.

Тобто значення речення у динамічній семантиці визначається як відношення між вихідним і результуючим інформаційними станами. Інформаційний стан індивіда виконує речення $\varphi$, якщо і тільки якщо дія на нього за допомогою вимовлянням цього речення не додає до нього нової інформації. А логічне випливання в цій семантиці має такий смисл: із послідовності речень $\varphi_{1}, \varphi_{2}, \ldots, \varphi_{n}$ логічно випливає речення $\psi$ тільки у тому випадку, коли при модифікації інформаційного стану індивіда послідовним вимовлянням речень $\varphi_{1}, \varphi_{2}, \ldots, \varphi_{n}$ вимовляння речення $\psi$ не додає нову інформацію.

Зміни в семантиці приводять до уточнення уявлень про дедукцію. Предметом аналізу стає не тільки і не стільки структура міркувань, скільки їх процесуальний характер. Причому динаміка виводу не зводиться до послідовності його кроків. Множина висновків може суттєво залежати від порядку застосування правил виводу, від можливих перестановок засновків. Динамічний підхід дозволяє експлікувати перехід від засновків до висновку, враховуючи специфіку дії на вивід кожного засновку. Тим самим з'являється можливість ефективно перевіряти правильність цього переходу [2].

Зручною формою представлення динамічного стилю висновків $є$ числення секвенцій. Аксіоми числення секвенцій мають вигляд формул $\varphi, \Gamma \Rightarrow \Theta, \varphi$. У цьому записі $\Gamma$ і $\Theta$ позначають довільні набори формул, а $\varphi$ - довільну формулу. Частина секвенції, яка стоїть зліва від стрілки є антецедентом секвенції. Справа від стрілки стоїть консеквент секвенції.

Розрізнення стилів виводу пов'язується із структурними правилами числення секвенцій. Ось їх список і коментарі до нього, що наведені у джерелі [7]: 
$\varphi \Rightarrow \varphi$

$\frac{X \Rightarrow \varphi \quad Y, \varphi, Z \Rightarrow \varphi}{Y, X, Z \Rightarrow \psi}$

$\frac{X, \varphi_{1}, \varphi_{2}, Y \Rightarrow \psi}{X, \varphi_{2}, \varphi_{1}, Y \Rightarrow \psi}$

$\frac{X, \varphi, Y, \varphi, Z \Rightarrow \psi}{X, \varphi, Y, Z \Rightarrow \psi}$

$\frac{X, \varphi, Y, \varphi, Z \Rightarrow \psi}{X, Y, \varphi, Z \Rightarrow \psi}$

$\frac{X, Y, \Rightarrow \psi}{X, \varphi, Y \Rightarrow \psi}$ рефлексивність

вирізання

перестановка

скорочення праворуч

скорочення ліворуч

монотонність (стоншення)

Секвенції, що знаходяться над рискою, виступають засновками відповідного правила, а секвенція, що знаходиться під рискою - його висновком. Правила монотонності, скорочення, рефлексивності і вирізання цілком детермінують класичне випливання. При динамічному підході відсутні деякі структурні правила стандартної логіки - правила монотонності, скорочення, перестановки. Правила рефлексивності і вирізання цілком детермінують динамічний вивід, а нові структурні правила

$\frac{X \Rightarrow \psi}{\varphi, X \Rightarrow \psi}$

монотонність ліворуч

$\frac{X \Rightarrow \varphi \quad X, \varphi, Z \Rightarrow \psi}{X, Z \Rightarrow \psi}$

вирізання ліворуч

цілком детермінують змішаний стиль виводу. Цей підхід вдало демонструє, як модифікуються правила виводу.

Наведені вище модифікації відношення логічного випливання були задумані їх авторами як засіб «схопити» динаміку міркування, його процедурний аспект. Однак динаміка виводу репрезентується не тільки типом правил, що застосовуються, але й порядком їх застосування, який задається відповідними умовами застосування.

Головна мета написання цієї статті полягає у тому, щоб привернути увагу до переходу від логічного моделювання статичних структур знання до логічного моделювання його динаміки. Відповідаючи тенденціям сучасної епістемології, цей перехід стимулює суттєві зміни у самій логіці. Інтерес до динамічних аспектів міркування вже привів, 
зокрема, до істотного оновлення логічної теорії значення. Подальші дослідження феномена скасовуваності висновків аргументативних дискурсів дозволять істотно розширити сферу прикладань символічної логіки і наші уявлення про той «динамічний поворот», який відбувається на сучасному етапі їі розвитку. Серед першочергових завдань розробка методів структуризації і репрезентації часткової, нечіткої, суперечливої інформації про допущення, які обгрунтовують висновки, i, зокрема, розробка методів, які не грунтуються на принципі несуперечливості. У логіці, як відомо, багато ментальних операцій розглядаються як особливі види міркування, а міркування як аргумент, що складається із засновків і висновку, в яких репрезентовані підстави і наслідок (теза аргументування). В цьому значенні логіка, яка репрезентує скасовуваність висновків, може бути застосована, наприклад, для реконструкції засобів обгрунтовування прийняття рішень.

Відмітною рисою всіх підходів, розглянутих вище, є трактування нового переконання як тавтологічного наслідку попередніх переконань. I це природно для дедуктивної репрезентації. Проте залишаються незачепленими дуже важливі для теорії аргументації проблеми. Зокрема, як охарактеризувати стан переконання, якщо в нього входять переконання, які не є прямими наслідками попередніх переконань? Iнша проблема полягає у тому, що переконання отримуються не тільки в результаті їх породження із істинних переконань. Аргументи можуть наводитись на підтримку явно хибних тверджень. Тому при аналізі аргументів необхідно враховувати не тільки логічні критерії коректності аргументування, але й різноманітні позалогічні критерії-правила мовного спілкування, моральні і правові норми тощо.

Аргументативний дискурс є складним комунікативним феноменом і уявлення про нього лише як про зв'язну послідовність повідомлень або мовних актів є вкрай недостатнім тоді, наприклад, коли виникає необхідність моделювати той спосіб, яким люди думають про аргументування, що здійснюється їхніми опонентами. Аргументативний дискурс містить не тільки відповідну сукупність вимовлянь, що породжують текст, але також і такі когнітивні компоненти як знання, опінії тощо. Когнітивний аналіз будь-якого дискурсу виходить із того, що зв'язність його актів обумовлена ментальними станами індивідів. Динаміка міркувань прямо залежить від динаміки цих станів. Тому на додаток до розробки засобів моделювання структури тексту, що породжується в ході дискурсу, необхідно розробляти засоби моделювання когнітивних процесів. Це, зокрема, дозволить зв'язати епістемічний і комунікативний аспекти аргументування - наведення підстав для по- 
ложення, що обгрунтовується, і навіювання інформації, що повідом-

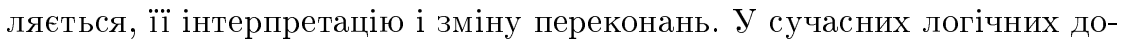
слідженнях з динаміки аргументації головним чином будуються саме ті моделі, у яких індивіди діють у динамічному і мультиагентному середовищі. У зв'язку з цим питання про скасовуваність висновків має розглядатися у більш широкому контексті сучасних уявлень про раціональність.

\section{1 Бібліог рафія}

[1] Alchourron C.E., Gardenfors P., Makinson D. On the Logic of Theory Change: Partial Meet Contraction and Revision Functions // Journal of Symbolic Logic. - 1985. - Vol. 50, № 2. - P. 510-530.

[2] Benthem, J. van. Logic and the Flow of Information.-Amsterdam: ILLC, University of Amsterdam, 1991.

[3] Groenendijk J., Stokhof M., Veltman F. Update Semantics for Modal Predicate Logic. - Amsterdam: ILLC, University of Amsterdam, 1994.

[4] Konolige K. Deduction Model of Belief and its Logic. - Menlo Park: SRI International, 1984.

[5] McDermott D., Doyle J. Non-Monotonic Logic I // Artificial Intelligence. - 1980. - V.13. - P. 41-72.

[6] Moore R.C. Semantical Considerations on Non-monotonic Logic // Artificial Intelligence. - 1985. - Vol. 25. — № 1. - P. 75-94.

[7] Muskens R., van Benthem J., Visser A. Dynamics // Handbook of Logic and Language (J. Van Benthem and A. Ter Meulen, editors). Elsevier: Amsterdam, Lausanne, New York, Oxford, Shannon, Tokyo; The MIT Press: Cambridge, Massachusetts, 1997. - P. 587-648.

[8] Priest G. Paraconsistent Belief Revision // Theoria.-2001. V. LXVII, Part 3. - P. 214-228. 